\title{
Analyzing the Antecedents of Duty Free Consumption Behavior
}

\author{
Yossi Gavish (PhD) \\ ONO Academic College \\ Academic Manager and senior lecturer in marketing. Israel \\ Aviv Shoham \\ Professor in marketing at the University of Haifa, Israel. \\ The Dean of the faculty of Management. Israel
}

\begin{abstract}
Consumers' duty free shopping represents an under-researched consumption behavior with far reaching economic and marketing implications. This study explores the extent to which personality trait impulsiveness, shopping enjoyment, and price prestige, mediated by shopping involvement and the perception of duty free shops influences buying intentions and actual buying in duty free shops. A convenience sample of 196 Israeli adults in Israel's Ben-Gurion International airport was used. A structural equation model was used to analyze the relationships among the model's variables. The model supports the positive impact of trait impulsiveness, shopping enjoyment, and price prestige on shopping involvement and perception of duty free shops. In addition, shopping involvement and duty- free shops perception enhanced buying intentions, which, in turn, increased several indicators of actual buying behavior. This paper contributes to the socio-psychology and marketing literatures by developing and testing an integrative model. It further provides implications for marketing managers and salespeople.
\end{abstract}

Keywords: shopping enjoyment, price prestige, consumption behavior, shopping involvement, duty free shops perception.

Article Classification - Research paper

\section{INTRODUCTION}

Duty free shops provide an important source of airports' budgets, which rely mostly on income from airlines and their passengers (59.6\%) and from commercial activities (40.4\%; Spinks, 2016). It has become a major income source of income accounting for $€ 15.4$ billion in 2015 (Graham, 2009; Moodie, 2007; Spinks, 2016). Not surprisingly then, countries seek to maximize income from duty free operations as a source of airport budgets (Park, et al., 2013). Consequently, identifying the antecedents of duty free shopping behavior is crucial for academicians and practitioners.

According to Freathy and O'connell (1999) there are dual relationship between shopping and tourism and therefore, airport managers no longer consider the transportation of passengers between one destination and another as the only aim of an airport. Vester (1996) suggested that many tourists consider an airport as a leisure attraction. At an airport, especially holiday or leisure travelers are motivated for tourism and leisure because they spent most time in the terminal. Finally, Geuens et al. (2004) argued that tourism and leisure activities are motivated by two needs: The first is the wish to contrast day-to-day or ordinary life routines and the second is the wish to be out-of-place. Those two motivational needs capture consumers in airport duty free shops in very unique circumstances 
In our model we test the relationships between the building blocks of our model, trait impulsiveness, shopping enjoyment, price prestige, shopping involvement and perceptions of duty free shops perception on buying intensions in duty free shops and actual buying in duty free shops. The effects of these concepts on buying intentions and actual buying are shown in the Model below.

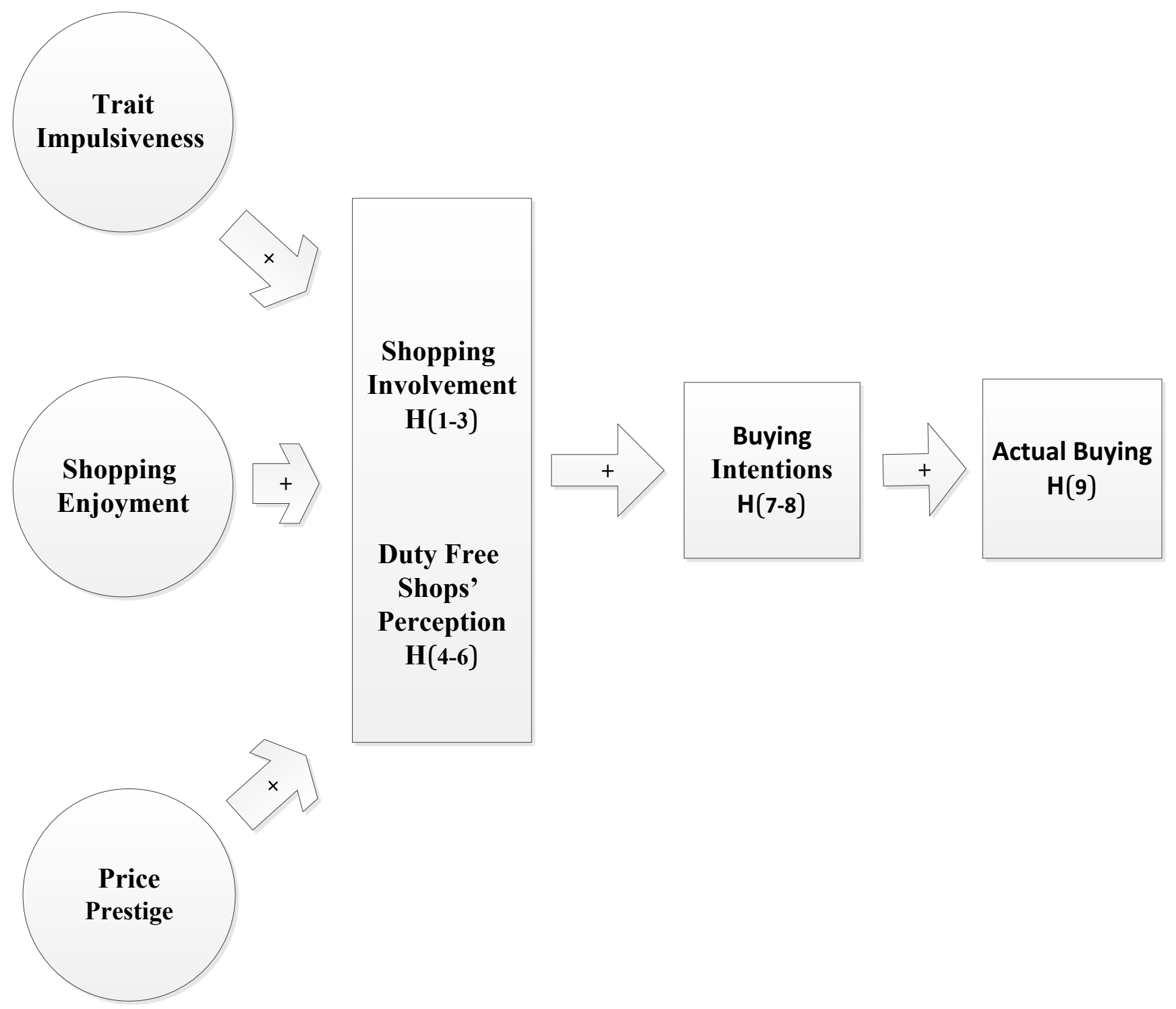

Figure 1. Antecedents and Outcomes of Duty Free Consumption Behavior

The principal contribution of the current study is the development of a model which integrates and extends existing knowledge on the relationships between variables such as impulsiveness, shopping enjoyment and price prestige on actual buying in a very unique environment, such as airport. In addition, most research in consumer behavior has been conducted in the US. Hence, the current study extends and validates issues regarding consumer behavior in Israel, which is more uncertainty avoidance than the US (Hofstede, 2001). Regarding using advance statistical technique, to the best of our knowledge no previous study tested these variables in integrative model using SEM procedure. Finally, theoretical implications regarding the mechanism that underlie consumers' shopping behavior in duty free shops as well as managerial insights into how marketers can leverage it.

In the remainder of this article, we discuss and hypothesize about the role of each antecedent of duty free shopping behavior. We then use SEM to test the hypothesized associations with 
data from a convenience sample of Israeli consumers and discuss the findings. Finally, we draw conclusions and offer theoretical and managerial implications.

\section{LITERATURE REVIEW AND RESEARCH HYPOTHESES}

\section{The relationships between impulsiveness, shopping enjoyment, and price prestige on} shopping involvement

Trait consumer impulsiveness. Early marketing literature described impulse buying simply as unplanned purchasing (Cobb \& Hoyer, 1986). Shahjehan, Qureshi, Zeb, \& Saifullah (2012, 2188) view trait consumer impulsiveness as "a tendency towards acting without forethought, making quick cognitive decisions, and failing appreciate the circumstances beyond the here and now". In a buying context, impulsive behavior refers to "swift action without forethought or conscious judgment, behavior without adequate thought, and the tendency to act with less forethought than do most individuals of equal ability or knowledge" (Moeller, et al. 2001, 1783).

Following critiques of this definition (Rook \& Gardner, 1993; Rook \& Hoch, 1985), Rook (1987, 191) defined impulse buying as occurring when "a consumer experiences a sudden, often powerful and persistent urge to buy something immediately". Stated differently, impulse buyers did not intend or plan to buy an item before entering a store; rather they succumb to a spontaneous urge without considering its consequences (Gerbing, et al., 1987).

In addition, Jones et al. (2003) showed that involvement have a great impact on consumers' tendency to purchase products of a particular category. According to Jones et al. $(2003,507)$ "product-specific impulse buying tendency can be viewed as a manifestation of the general impulse buying tendency trait". Moreover, Davis and Sajtos (2009) found that using SMSservices impulsively was related positively to general impulse buying tendency.

Two emotional shifts could affect airport consumer behavior (Ogenyi \& Kent, 2001; Thomas, 1997). First, consumers step outside of daily routines leading to heightened stress. Second, the airport environment increases excitement. When consumers enter the airport, stress declines but excitement remains high. Thomas (1997) labeled this excitement as "happy hour" suggesting that buying behavior at the airport is expression of this happy hour. This is the time that impulsive shopping is likely to occur. In sum:

\section{$H_{1}$ There is a positive relationship between trait impulsiveness and shopping involvement.}

Shopping enjoyment. Odekerken-Schroeder, De Wulf, and Schumacher $(2003,181)$ defined shopping enjoyment as "a consumer's personality trait representing the tendency to find shopping more enjoyable and to experience greater shopping pleasure than others." Shopping enjoyment is often related with hedonic motivation. Following classical motivational principles, Higgins (2006) argued that hedonic motivation refers to the impact of individuals' pleasure/pain organs on their willingness to approach goals or avoid threats. Emotional experiences range from bad to good and individuals are motivated to seek the "good" point of the range (Higgins, 2006). From a marketer's perspective, the goal in duty free shops is to increase the probability of actual buying. Many consumers derive intrinsic enjoyment from the process of shopping (Cox, et al. 2003), hence, hedonic motivation plays a crucial factor. Similarly, Falk and Campbell $(1997,189)$ noted that "...there is little doubt that many people do obtain great pleasure from shopping... and that shopping is a leisure time pursuit that has increased in importance in recent decades. However, it is not entirely clear what exactly constitutes the source of the pleasure". Hirschman and Holbrook, $(1982,92)$ stated, "Hedonic consumption designates those facets of consumer behavior that relate to the multi-sensory, fantasy and emotive aspects of one's experience with products." According to them (p. 92), 
"shopping is part of the experience of the product but "retail mall" could replace "product" and hedonic consumption can be directly linked with the mall shopping experience in and of itself." In light of the above, airport duty free shopping enjoyment should be viewed a "retail mall" rather than be divided into separate shops.

In addition, Clements and Josiam (2005) argued that level of involvement is related with motivation for leisure choice. Studying students and their involvement with spring break vacation, they found that spring break travelers non-travelers during were highly involved with spring break travel. However, travelers demonstrated higher levels of involvement. As a result, they inferred that higher levels of involvement and variables such as time and money to overcome barriers to travel are positive related. In sum:

$\mathrm{H}_{2}$ : There is a positive relationship between shopping enjoyment and shopping involvement.

Price-Prestige perceptions. The marketing literature has discussed prestige brands for decades (Andrus, et al., 1986). Lichtenstein et al. $(1993,236)$ defined the term prestige sensitivity as "favorable perceptions of price, based on the feeling of prominence and status that higher prices signal to other people about the purchaser". In addition, buying very expensive and prestige brands may stem from a snob effect (Vigneron \& Johnson, 1999), which occurs when a new luxury product is introduced and the show-off segment adopts it first.

Laurent and Kapferer (1985) suggested that involvement is a motivating variable with a number of consequences on the consumer's purchase and communication behavior. In marketing contexts, price has been used frequently as an indicator of involvement. The higher the price the higher the risks of making wrong buying decisions and the more likely are consumers to be involved (Rothschild, 1979). Durable goods also lead to high involvement because of the resulting extended period of owning a poor product. High-involvement is also typical in purchases of clothing due to their social symbolic meaning and their capacity to express hedonic character and lifestyle (Hirschman \& Holbrook, 1982; Levy, 1959).

Finally, prestige products have also been used as examples of high-involvement decisionmaking (Vigneron \& Lester, 1999). Purchased infrequently, prestige products need a high level of interest and knowledge and are part of a person's self-concept. According to Rossiter, Percy, and Donovan (1991), the distinction between high- and low-involvement is mostly dichotomous. Presenting "informational-transformational" as a second dimension, they assumed that prestige or luxury products are high-involvement ones. Further, they argued that transformational brand choices are the most important factors in selecting prestige products. In sum:

\section{$H_{3:}$ There is a positive relationship between price prestige and shopping involvement.}

\section{The effects of impulsiveness, shopping enjoyment and price prestige on perceptions of duty free shops}

Trait impulsiveness. According to Newman and Foxall (2003), given the character of fashion shoppers and the impulsiveness that goes with buying fashion products, a shop configuration fitting these individuals will make their moods more positive. They argued that in-store cues were important store features, which retailers could use to create a store image fitting consumers' perceptions of the store. Examples include music (Antonides \& Raaij, 1998; Baker, et al., 1994), merchandise (Baker, et al., 1994), moods, layout, signage, (Newman, et al., 1996), retail atmosphere and smell (Antonides \& Raaij, 1998; Chebat \& Dub, 2000), colors (McKenna, 2000), and store image attributes (Birtwistle \& Shearer, 2001). Hence, individuals' impulsiveness and perceptions of duty free stores should be related positively. In sum:

$\mathrm{H}_{4}$ : Trait impulsiveness and perceptions of duty free shops are related positively. 
Shopping enjoyment refers to an individual's personality trait that tends to rate shopping trips as more enjoyable than other consumers often do (Bellenger \& Korgaonkar, 1980; OdekerkenSchroeder, et al., 2003). Shopping enjoyment is associated with emotional responses such as satisfaction, excitement, and dominance (Dawson, et al., 1990; Koufaris, et al., 2001). It plays a major part in pulling shoppers to visit shopping malls. Excitement also tends to increase consumers' satisfaction with a store and, as a result, the lengths of time shoppers spend in it (Babin \& Darden, 1996). Shopping loving consumers spend more time shopping per trip and are less likely to know what they will buy during their trip (Forsythe \& Bailey, 1996).

Regarding store perception, Martineau (1958) suggested that store image could be defined in consumers' minds as a combination of the store's psychological and functional qualities. He found that the more positive a store's image, the more likely consumers are to enjoy shopping and buying in it. Others have highlighted store image as a multi-dimensional concept strongly affecting retail patronage (Erdem, et al., 1999; Kim \& Jin, 2001). In sum:

$H_{5}:$ There is a positive relationship between shopping enjoyment and duty free shop perceptions.

Price-Prestige. Lacking information about product quality, consumers tend to base purchase decisions on inferences from other information cues (Bloom \& Reve, 1990; Zeithaml, 1988). One important cue is the retail shop environment. It offers a mix of stimuli that can serve as cues to consumers using information-processing heuristics (Baker, Grewal, \& Parasuraman, 1994). For example, dense carpeting and low-level lighting may lead customers to infer that the store sells high quality goods or offers high quality service (Baker, Grewal, \& Parasuraman, 1994). Hence, such cues could affect a shop's image. Erickson and Johansson (1985) noted that for some consumers, price is used as an indicator of product quality. Such consumers view higher prices favorably because of perceptions of higher product quality (Lichtenstein, Bloch, \& Black, 1988). Duty free stores' image refers to "stereotypic image of the generalized (typical) user of a particular retail store" (Sirgy \& Samli, 1985, 271). Later, Bloemer and Ruyter (1997, 501) defined store image as "The complex of a consumer's perceptions of a store on different (salient) attributes". For example, Doyle and Fenwick (1974) distinguished five elements of a store's image: product, assortment price, styling, and location. Regardless of the number of elements, the dominant attitudinal perspective treats store image as the result of a multiattribute model (Marks, 1976).

In sum, we propose:

\section{$H_{6}:$ There is a positive relationship between price prestige and duty free shop's perceptions}

The effect of shopping involvement and duty free shops perception on buying intentions Shopping involvement. Zaichkowsky $(1985,342)$ defined involvement as "a person's perceived relevance of the object based on inherent needs, values and interests". This definition includes categories such as products, purchase decisions and advertisements. Under high involvement conditions, consumers experience an extended problem-solving process.

Involvement as a motivating force is activated when a product or promotional message is perceived as instrumental in fulfilling important needs, goals, and values (Vermeir \& Verbeke, 2006). In this context, Zaichkowsky $(1985,342)$ defined involvement as "a person's perceived relevance of the object based on inherent needs, values and interests". Objects are important when they address important values and goals. In such cases, highly involved people are motivated to invest cognitive decision-making efforts. Involvement affects formation of beliefs, attitudes, and buying intentions and increases extensiveness of information search, the length 
of the decision-making process, and shopping enjoyment (Beharrel \& Dennison, 1995; Sullivan \& Heitmeyer, 2008; Verbeke \& Vackier, 2004). In sum:

$H_{7}$ : There is a positive relationship between shopping involvement and buying intentions.

Tourist Shopping Habitat (TSH) refers to the locations where tourists hang around for utilitarian and hedonic activities including shopping (Bloch, et al., 1994; Yu"ksel, 2007). Unlike organized shopping malls, a TSH includes multi-type retailers, each with a unique atmospheric image. Atmospherics include colors, scents, and music. According to Snepenger et al. (2003), TSH's retail mix includes gift shops, restaurants, bars, and street vendors, at times located in historical buildings. TSHs exhibit unstructured environments, provide location-based activities, have friendly atmospheres and allow tourists to experience authentic customs and cultures thus making them prime shopping attractions (Hsieh \& Chang, 2006). Especially noteworthy is the freedom shoppers sense, which is coupled with reduce perceptions of budget constraints. In total, these freedom perceptions, felt in leisure experiences, increase buying intentions and behaviors (Yu"ksel, 2007). In sum:

$H_{8}:$ There is a positive relationship between duty free shops perception and buying intentions

\section{The effect of buying intentions on actual buying}

The theory of planned behavior suggested that behaviors are functions of perceived behavioral control and intentions. The relationships between intentions and actions have been demonstrated numerous times across multiple types of behaviors (Sheppard, et al., 1988). Behaviors can be predicted from intentions with high accuracy especially when there are few control problems (Ajzen, 1991; Sheppard, et al., 1988). Thus, it is not surprising that using the theory of planned behavior, Tarkiainen and Sundqvist (2005) showed that behaviors are common outcomes of perceived behavioral control and intentions.

Several examples should suffice to show the robustness of these relationships. For example, buying intentions anteceded Chinese consumers' ownerships of Japanese products (Klein, et al., 1998). Another example in a different context, Hines, Hungerford and Tomera (1987) found the same relationship in the context of environmental behavioral intentions and environmental behavior. Likewise, according to Ishii (2009), Chinese consumers' willingness to buy Japanese or American products and buying imports from Japan or the United State were related positively. In sum:

\section{$H_{9:}$ There is a positive relationship between buying intentions and actual buying.}

\section{Data Collection and Sample Characteristics}

\section{RESEARCH METHOD}

Data were collected in Israel's Ben-Gurion international airport by students, who received thorough instruction and training in research methodology. Student teams were trained on how to approach non-business-related travelers and administer the survey. They were given guidelines regarding desired characteristics (gender and ages) and distributed 350 questionnaires among visitors. Of these, 274 questionnaires were returned of which 78 were incomplete. The final sample included 196 individuals (56\% rate). Given this high response rate, non-response does not appear to be a problem in this research.

Students were instructed to aim for a representative sample of the adult Israeli population ( $\geq$ 18 years old). The sample reflects a gender-balanced composition (94 males; 102 females). Additionally, income was distributed almost normally $24.5 \%$ are lower than the average annual household income, $31.6 \%$ are around the average household income and $43.9 \%$ are higher than the average household income). Education was also normally distributed (24\% 
under 12 years, 34.7\% 13-15 years and $43.9 \%$ over 16 years). Table 1 provides a description of the sample.

Table 1. Sample Characteristics ( $\mathrm{N}=196)$

\begin{tabular}{lll}
\hline Variable & $\mathbf{N}$ & $\mathbf{0}$ \\
\hline Age & 52 & 26.5 \\
$18-29$ & 55 & 28.1 \\
$30-39$ & 29 & 14.8 \\
$40-49$ & 48 & 24.5 \\
$50-59$ & 12 & 6.1 \\
60+ & & \\
Education (years) & 48 & 24.5 \\
12 or less & 62 & 31.6 \\
13-15 & 86 & 43.9 \\
16 or more & & \\
Income & 47 & 24.0 \\
Lower than the average & 68 & 34.7 \\
Similar to the average & 81 & 41.3 \\
Higher than the average & & \\
Gender & & 48.0 \\
Male & 94 & 52.0 \\
Female & 102 &
\end{tabular}

\section{Measures}

Data were collected through a structured, self-administered questionnaire with seven scales and demographic items. As all scales were originally in English, a conventional backtranslation technique was used. One bilingual individual translated the original questionnaire to Hebrew. A second bilingual individual, blind to the original questionnaire, back-translated the Hebrew version into English. Then, the two translators and one of the authors evaluated the translations for wording, content, and local applicability and equivalence. Minor disagreements were resolved in this stage leading to the final version. Table 2 and table 3 present scales' correlations, reliabilities, standard deviations and means. Table 4 presents scales' items and authors. 
Table 2. Scales' Correlations

$\begin{array}{lllllllllll}1 & 2 & 3 & 4 & 5 & 6 & 7 & 8 & 9 & 10 & 11\end{array}$

Trait

Impulsiveness

Shopping

Enjoyment

$.54^{* *}$

Price Prestige

$.45^{* *} \quad .38^{* *}$

Shopping

Involvement

$.41^{* *} \quad .40^{* *} \quad .41^{* *}$

Perceived Duty

Free Shops

$.39^{* *} \quad .41^{* *} \quad .32^{* *} \quad .50^{* *}$

Buying Intentions

$.21^{* *}$

$.20^{* *} \quad .31^{* *}$

$.22^{* *}$

Actual Buying (1)

$\begin{array}{lllll}.27^{* *} & .30^{* *} & .25^{* *} & .28^{* *} & .33^{* *}\end{array}$

Actual Buying (2)

.06

$.31^{* *}$

$.25^{* *} \quad .40^{* *}$

$.53^{* *}$

Actual Buying (3)

$.23^{*}$

.14

$.23^{* *}$

$.10 \quad .42^{* *}$

$.43^{* *} \quad .35^{* *}$

Actual Buying (4)

$.22^{* *}$

$.36^{* *}$

$.25^{* *}$

$.38^{* *}$

$.30^{* *} \quad .41^{* *} \quad .45^{* *}$

Actual Buying (5)

$.06 \quad .19^{*}$

$.11 \quad .17^{*} \quad .20^{* *}$

$.32^{* *}$

$.21^{* *}$

$.22^{* *}$

.14 $.44^{* *}$

** Correlation is significant at the 0.01 level (2-tailed).

Table 3. Scales' Reliabilities ( $\alpha$ ), Standard Deviations and Means

Scale

Reliability Standard

Mean

Deviation

Trait Impulsiveness

.91

1.13

2.4

Shopping Enjoyment

.93

1.24

2.79

Price Prestige

.89

1.14

Shopping Involvement

.92

Perceived Duty Free Shops

1.64

Buying Intentions

.81

0.93

2.77

2.69 
Table 4. Scales' Items

\begin{tabular}{|c|c|c|}
\hline $\begin{array}{c}\text { Scale's } \\
\text { Name }\end{array}$ & Authors & Items \\
\hline $\begin{array}{l}\text { Trait } \\
\text { Impulsiveness }\end{array}$ & Rock and Fisher (1995) & $\begin{array}{l}\text { I often buy things spontaneously. } \\
\text { "Just do it" describes the way I buy things. } \\
\text { I often buy things without thinking. } \\
\text { "I see it, I buy it" describes me. } \\
\text { "Buy now, think about it later" describes me. } \\
\text { Sometimes I feel like buying things on the spur-of-the moment. } \\
\text { I buy things according to how I feel at the moment. } \\
\text { I carefully plan most of my purchases (r). } \\
\text { Sometimes I am a bit reckless about what I buy. }\end{array}$ \\
\hline $\begin{array}{l}\text { Shopping } \\
\text { Enjoyment }\end{array}$ & $\begin{array}{l}\text { Shim and Gehrt (1996) - Items 1-4 } \\
\text { O'Guinn and Faber (1989) - Items 5-6 }\end{array}$ & $\begin{array}{l}\text { Shopping is not a pleasant activity to me (r). } \\
\text { Going shopping is one of the enjoyable activities of my life. } \\
\text { Shopping the stores wastes my time (r). } \\
\text { I enjoy shopping just for the fun of it. } \\
\text { I shop because buying things makes me happy. } \\
\text { I get a real "high" from shopping. }\end{array}$ \\
\hline Price Prestige & $\begin{array}{l}\text { Lichtenstein, Ridgway and Netemeyer } \\
\text { (1993) }\end{array}$ & $\begin{array}{l}\text { People notice when you buy the most expensive brand of a product. } \\
\text { Buying a high priced brand makes me feel good about myself. } \\
\text { Buying the most expensive brand of a product makes me feel classy. } \\
\text { I enjoy the prestige of a high priced brand. } \\
\text { It says something to people when you buy the high priced version of a } \\
\text { product. } \\
\text { Your friends will think you are cheap if you consistently buy the lowest } \\
\text { price version of a product. } \\
\text { I have purchased the most expensive brand of a product just because I } \\
\text { knew other people would notice. } \\
\text { I think others make judgments about me by the kinds of products and } \\
\text { brands I buy. } \\
\text { Even for a relatively inexpensive product, I think that buying a costly } \\
\text { brand is impressive. }\end{array}$ \\
\hline $\begin{array}{l}\text { Shopping } \\
\text { Involvement }\end{array}$ & Unger and Kerman (1983) & $\begin{array}{l}\text { It helps me forget about the day' problems. } \\
\text { It totally absorbs me. } \\
\text { It is like "getting away from it all". } \\
\text { It makes me feel like I'm in another world. } \\
\text { I could get so involved that I would forget everything else. }\end{array}$ \\
\hline $\begin{array}{l}\text { Perceived } \\
\text { Duty Free } \\
\text { Shops }\end{array}$ & $\begin{array}{l}\text { Hawes and Lumpkin (1986) - Item } 1 \\
\text { Baker at al. (1994) - Items 2-4 } \\
\text { Wu and Petroshius (1987) - Items 5-6 } \\
\text { Authors - Items 7-12 }\end{array}$ & $\begin{array}{l}\text { I enjoy shopping in duty free shops. } \\
\text { Duty free shops would be a pleasant place to shop. } \\
\text { The duty free shops have a pleasant atmosphere. } \\
\text { Duty free shops are attractive. } \\
\text { Duty free shops have attractive layout. } \\
\text { Duty free shops are prestigious. } \\
\text { I find duty free shops as tempting. } \\
\text { Duty free shops are a temptation for me. } \\
\text { I see duty free shops as enchanting. } \\
\text { Duty free shops are irresistible for me. } \\
\text { I find it difficult to leave duty free shops without buying something. } \\
\text { When I pass by duty free shops they tempt me to enter and buy. }\end{array}$ \\
\hline
\end{tabular}

Impulsiveness was measured using Rook and Fisher (1995) 9-item scale. The scale's reliability was acceptable $(\alpha=.91)$. Shopping Enjoyment was measured by a 6 -item scale. Items $1-4$ were taken from the scale developed by Shim and Gehrt (1996). Items 5-6 were added from a scale developed by O'Guinn and Faber (1989). The scale's reliability was acceptable $(\alpha=.93)$.

Price Prestige was measured by Lichtenstein, Ridgway and Netemeyer's (1993) 9-item scale. The scale's reliability was acceptable $(\alpha=.89)$. Shopping Involvement was measured by Unger and Kerman's (1983) 5-item scale. The scale's reliability was acceptable $(\alpha=.92)$.

Finally, Duty Free Shops Perception was measured by a 12 -item scale. Since no pre-existing scale was identified in the literature, we adapted items from several related scales. Item 1was 
adapted from Hawes and Lumpkin (1986). Items 2-4 were adapted from Baker et al. (1994). Items 5-6 were adapted from $\mathrm{Wu}$ and Petroshius' (1987) scale. Items 7-12 were developed by the authors. The scale's reliability was acceptable $(\alpha=.92)$.

\section{Model Estimation}

Given the sample size and the required number of estimates in the analysis, we used a parceling procedure. First, a measurement model assessed the items' correspondence with their respective latent variables (Anderson \& Gerbing, 1982, 1988). The measurement model resulted in acceptable fit statistics. Specifically, the $\chi^{2} /$ degrees of freedom ratio was $1.57\left(\chi^{2}=\right.$ 891.3, df = 568; $\mathrm{p} \leq .01$ ), well below the recommended level of 5.0 (Hair, et al., 1998). Similarly, IFI (.93), CFI (.93) and TLI (.92) were above the recommended .90 level and RMSEA $=.07$, under the recommended .08 level. In sum, the measurement model satisfied the required fit criteria, allowing for further examination of the substantive model.

\section{EMPIRICAL RESULTS}

The substantive model had acceptable fit measures. Specifically, the $\chi^{2} /$ degrees of freedom ratio was $1.57\left(\chi^{2}=997.4 ; \mathrm{df}=571 ; \mathrm{p} \leq .01\right)$, well below the recommended level of 5.0 (Hair, et al., 1998). Similarly, CFI (.93), IFI (.93) and TLI (.92) met the recommended .90 level and the RMSEA was at .07 level, under the recommended .08 level. In sum, the model satisfied the required fit criteria and the results are presented in Table 5.

Table 5. SEM Results

\begin{tabular}{|c|c|c|c|}
\hline Hypothesis & Relationship & $\beta / \gamma$ & P-Value \\
\hline $\mathrm{H}_{1}$ & Trait impulsiveness $\rightarrow$ Shopping involvement $(+)$ & .22 & .01 \\
\hline $\mathrm{H}_{2}$ & Shopping enjoyment $\rightarrow$ Shopping involvement $(+)$ & .20 & .02 \\
\hline $\mathrm{H}_{3}$ & Price prestige $\rightarrow$ Shopping involvement (+) & .27 & .00 \\
\hline $\mathrm{H}_{4}$ & Trait impulsiveness $\rightarrow$ Perceived Duty - Free shops $(+)$ & .18 & .06 \\
\hline $\mathrm{H}_{5}$ & Shopping enjoyment $\rightarrow$ Perceived Duty - Free shops $(+)$ & .26 & .00 \\
\hline $\mathrm{H}_{6}$ & Price prestige $\rightarrow$ Perceived Duty -Free shops (+) & .18 & .04 \\
\hline $\mathrm{H}_{7}$ & Shopping involvement $\rightarrow$ Buying intentions (+) & .38 & .00 \\
\hline $\mathrm{H}_{8}$ & Perceived Duty -Free shops $\rightarrow$ Buying intentions $(+)$ & .16 & .08 \\
\hline \multirow[t]{5}{*}{$\mathrm{H} 9$} & Buying intentions $\rightarrow$ Actual buying (1) $(+)$ & .52 & .00 \\
\hline & Buying intentions $\rightarrow$ Actual buying (2) (+) & .55 & .00 \\
\hline & Buying intentions $\rightarrow$ Actual buying (3) (+) & .60 & .00 \\
\hline & Buying intentions $\rightarrow$ Actual buying (4) (+) & .57 & .00 \\
\hline & Buying intentions $\rightarrow$ Actual buying (5) (+) & .37 & .00 \\
\hline
\end{tabular}

\section{Fit statistics}

$\chi^{2}=897.4 ; 571$ degrees of freedom; $\chi^{2} / \mathrm{df}=1.57 ;$ RMSEA $=.07 ; \mathrm{IFI}=.93, \mathrm{CFI}=.93$, TLI=.90

We expected trait impulsiveness to be positively associated with shopping involvement $\left(\mathrm{H}_{1}\right)$. The data supported this hypothesis $(\beta=.22 ; p=.01)$. We expected shopping enjoyment to be positively associated with shopping involvement $\left(\mathrm{H}_{2}\right)$. The data supported this hypothesis $(\beta=$ $.20 ; p=.02$ ). We expected price prestige to be positively associated with shopping involvement $\left(\mathrm{H}_{3}\right)$. The data supported this hypothesis $(\beta=.27 ; p=00)$.

We expected trait impulsiveness to be positively associated with perceived duty free shops $\left(\mathrm{H}_{4}\right)$. The data provided marginal support to this hypothesis $(\beta=.18 ; p=.06)$. We expected 
shopping enjoyment to be positively associated with perceived duty free shops $\left(\mathrm{H}_{5}\right)$. The data supported this hypothesis $(\beta=.26 ; p=.04)$.

We expected price prestige to be positively associated with perceived duty free shops $\left(\mathrm{H}_{6}\right)$.The data supported this hypothesis $(\beta=.18 ; p=.04)$. We expected shopping involvement to be positively associated with buying intentions $\left(\mathrm{H}_{7}\right)$. The data supported this hypothesis $(\beta=$ $.38 ; p=.00)$.

We expected perceived duty free shops to be positively associated with buying intentions $\left(\mathrm{H}_{8}\right)$. The data marginally supported this hypothesis $(\beta=.16 ; p=.08$, M.S). We expected buying intentions to be positively associated with actual buying $\left(\mathrm{H}_{9}\right)$. The data supported this hypothesis $\left(\beta_{1}=.52 ; \beta_{2}=.55 ; \beta_{3}=.60 ; \beta_{4}=.57 ; \beta_{5}=.37\right.$ : all at $\left.p=.00\right)$.

\section{Theoretical Implications}

\section{DISCUSSION}

This study examined the relationship among personality trait impulsiveness, shopping enjoyment, price prestige and outcomes including shopping involvement, perceived duty free shops, buying intentions, and actual buying. Given the lack of an integrative study on duty free shopping, our study provides important theoretical and practical insights. In addition, a vast majority of research on some of the relationships discussed here has been conducted in the US (e.g., behavioral intentions $\rightarrow$ behaviors). Thus, the current study validates some previous findings in the different Israeli culture. Specifically, Israel is a less individualistic (Israel IDV=51; USA IDV=91), more uncertainty-avoiding (Israel UAI=81; USA UAI=46), and less power-distant accepting (Israel PDI=13; USA PDI=40) than the United States is (Hofstede, 2001).

\section{Shopping Involvement}

The relationship between trait impulsiveness and shopping involvement was positive in support of Jones et al. (2003), who suggested that involvement influences consumers' tendency to buy products of a specific category on impulse. In addition, our findings support Davis and Sajtos' (2009) findings, according to which the impulsive use of SMS-services is a function of a general impulse buying tendency. Thus, the current study extends previous impulsiveness involvement relationship to duty free shoppers.

The relationship between shopping enjoyment and shopping involvement was positive. This is in line with Clements and Josiam (2005), who argued that involvement should be related with motivation for leisure choice. They suggested that both travelers and non-travelers during the spring break were mostly categorized as 'high involvement' with spring break travel. However, travelers demonstrated higher levels of involvement. As a result, they inferred that those with higher levels of involvement found the time and money to overcome the barriers to travel and actually traveled during the spring break.

The relationship between price prestige and shopping involvement was positive. This is in line with a large body of research showing that prices are a commonly used indicator of involvement. For example, the risks of a mis-purchase are high when price is high; hence, consumers are likely to be highly involved (Rothschild, 1979). Our study extends previous finding to duty free shoppers.

\section{Duty free Shops Perception}

The relationship between trait impulsiveness and perceptions of duty free shops was positive. As noted earlier, marketing studies have emphasized the importance of in-store architecture 
and cues for retailers and consumers (Newman \& Foxall, 2003). In addition, they found that in case of fashion buyers and the impulsiveness that surrounds buying behavior, a more accurate shop configuration lead to positive changes in shoppers' mood.

Shopping enjoyment and perceptions of duty free shops' image were related positively. Our findings are in line with Martineau (1958), who suggested that the more favorable the shop image and its perception by consumers, the more likely the consumers would enjoy shopping and buy at this shop. Wong et al. (2012) argued that the atmosphere of the shop is often designed to influence on shoppers' emotions. In fact, in-store elements such as scent, color, lighting, music displays, friendly employees, product demonstrations or samples are designed to create positive feelings and enjoyment within shopper in the environment (Solomon, 2007).

The relationship between price prestige and perceptions of duty free shops was positive. Previous studies found that in-store cues, such as high prices could lead shoppers to infer that the store sells high quality products or offers high quality service (Baker, Grewal, \& Parasuraman 1994; Lichtenstein, Bloch, \& Black, 1988).

\section{Buying Intentions}

The relationship between shopping involvement and buying intentions was positive. Our findings support Sullivan and Heitmeyer (2008), who argued that involvement influences purchase behavior and shopping motivations.

The relationship between perceptions of duty free shops and buying intentions was positive. Previous finding regarding the atmosphere in duty free shops emphasized the freedom that shoppers feel in duty free and that they have sense of no limited budget constraints. This may lead to their overall leisure experiences and increasing buying intentions and behaviors (Yu"ksel, 2007).

\section{Actual Buying}

The relationship between buying intentions and actual buying was positive. Previous findings support this relationship. Klein et al. (1998) found that buying intentions were significant predictors of Chinese consumers' ownerships of Japanese products. This relationship was also documented by Hines, Hungerford, and Tomera (1987) in a different context of environmental behavioral intentions and environmental friendly behavior.

\section{Managerial Implications}

Our results provide several managerial implications at two different levels. One level is that of managers of duty free zones and all shops in it and another, more specific, at the level of each shop separately.

First, shopping enjoyment and price prestige enhanced shopping involvement and perceptions of duty free shops. From the perspective of general management of the zone, management should strive to increase shoppers' out of stores enjoyment. This can be achieved by creating family-oriented activities in the general area. Another option could be zone-wide specials. At the level of specific stores, increasing shopping enjoyment is a prime managerial target. The relevant tools for this purpose do not differ from creating enjoyment in any retail outlet, including the use of music and lights. The idea is to increase consumers' involvement and instore enjoyment by investing in shop atmospheres (Antonides \& Raaij, 1998; Chebat \& Dub, 2000). Shop atmospherics describe the unique qualities of retail means that are often designed to elicit positive consumer responses. For example, better-illuminated merchandise can entice shoppers to visit a shop, linger, and make purchases (Summers \& Hebert, 2001). Alternatively, 
background music is enticing in luxury category, tempting in fashion stores, and likely to attract consumers to visit stores that play music they like (Broekemier, Marquardt \& Gentry, 2008). In short, retail managers believe, and observations confirm that friendly and pleasant atmosphere lead consumers to buy more since they tend to stay in the shop for longer time (Verma, 2013).

Second, regarding price-prestige perceptions, "outdoor" advertising would be an excellent tool for managers of the duty free zone. Signage can be designed to convey messages about the manner in which each store in the zone provides high price-prestige delivery. Each store then should follow with similar messages at the store-level. Naturally, such emphases require tight coordination of messages and executions between zone managers and store managers.

While our study has implications for researchers and marketers, it is not without limitations that can be addressed in future studies. First, we used a convenience sample, which could limit the generalizability of its findings. Future research can use random airport sampling. Second, our study included only Israeli shoppers. Future research should test our model in other cultures to provide external validity to our findings. Alternatively, data can be collected from non-Israelis at the airport. Finally, in the current study shoppers were asked about their buying intentions and behavior in duty free shops in general. We suggest testing our model in specific categories of products such as electronics, cosmetics and jewelry.

\section{References}

Ajzen, I. (1991). The theory of planned behavior, Organizational Behavior and Human Decision Processes, 50 (2), 179-211: https://doi.org/10.1016/0749-5978(91)90020-T

Andrus, M.D., Silver, E., \& Dallas, E.J. (1986). Status brand management and gift purchase: A discriminant analysis, Journal of Consumer Marketing, 3 (1), 5-13: http://doi.org/10.1108/eb008149

Antonides, G., \& Raaij, W.F.V. (1998). Consumer behavior: A European perspective, John Wiley \& Sons, Chichester.

Baker, J., Grewal, D., \& Parasuraman, A. (1994). The influence of store environment on quality inferences and store image. Journal of the Academy of Marketing Science, 22 (4), 328-339:

https://doi.org/10.1177/0092070394224002

Baker, J., Parasuraman, A., Grewal, D., \& Voss, G.B. (2002). The influence of multiple store environment cues on perceived merchandise value and patronage intentions. Journal of Marketing, 66 (2), 120-141:

https://doi.org/10.1509/jmkg.66.2.120.18470

Beatty, S.E., \& Ferrell, M.E. (1998). Impulse buying: modeling its precursors. Journal of Retailing, 74 (2), 169-191: https://doi.org/10.1509/jmkg.66.2.120.18470

Beharrell, B., \& Denison, T.J. (1995). Involvement in a routine food shopping context. British Food Journal, 97 (4), 24-29: http://doi.org/10.1108/00070709510085648

Bellenger, D.N., \& Korgaonkar, P. (1980). Profiling the recreational shopper. Journal of Retailing, 56 (3), 77-92.

Birtwistle, G., \& Shearer, L. (2001). Consumer perception of five UK fashion retailers. Journal of Fashion Marketing and Management, 5 (1), 9-18: http://doi.org/10.1108/eum0000000007275

Bloch, H.P, Ridgway, M.N., \& Dawson, A.S. (1994). The shopping mall as a consumer habitat. Journal of Retailing, 70 (1), 23-42: https://doi.org/10.1016/0022-4359(녀)

Bloemer, J., \& De Ruyter, K. (1998). On the relationship between store image, store satisfaction and store loyalty. European Journal of Marketing, 32 (5/6), 499-513: http://doi.org/10.1108/03090569810216118

Bloom, P.N, \& Reve, T. (1990). Transmitting signals to consumers for competitive advantage. Business Horizons, 33 (4), 58-66.

Broekemier, G., \& Marquardt, R., \& Gentry, J. (2008). An exploration of happy/sad and liked/disliked music effects on shopping intentions in women's clothing store service setting. Journal of Service Marketing, 22 (1), 59-67: http://doi.org/10.1108/08876040810851969 
Clements, C.J., \& Josiam, B. (1995). Role of involvement in the travel decision. Journal of Vacation Marketing, 1 (4), 337-348: https://doi.org/10.1177/135676679500100403

Chebat, J.C., \& Dub, L. (2000). Evolution and challenges facing retail atmospherics: The apprentice sorcerer is dying. Journal of Business Research, 49 (2), 89-90.

Cobb, J.C., \& Hoyer, D.W. (1986). Planned versus impulse purchase behavior. Journal of Retailing, 62 (Winter), $384-$ 499.

Cox, A.D., Cox, D., \& Anderson, R.D. (2005). Reassessing the pleasures of store shopping. Journal of Business Research, 58 (3), 250-259: https://doi.org/10.1016/S0148-2963(03)00160-7

Davis, R., \& Sajtos, L. (2009). Anytime, anywhere: Measuring the ubiquitous consumer's impulse purchase behavior. International Journal of Mobile Marketing, 4 (1), 15-22.

Dawson, S., Bloch, P.H., \& Ridway, N.M. (1990). Shopping motives, emotional states and retail outcomes. Journal of Retailing, 66 (4), 408-427.

Doyle, P., \& Fenwick, I. (1974). Shopping habits in grocery chains. Journal of Retailing, 50 (4), 39-52.

Erdem, O., Oumlil, A.B., \& Tuncalp, S. (1999). Consumer values and importance of store attributes. International Journal of Retail and Distribution Management, 27 (7), 137-144: http://doi.org/10.1108/09590559910268435

Erickson, M.G, \& Johansson, K.J. (1985). The role of price in multi-attribute product evaluations. Journal of Consumer Research, 12 (September), 195-199: https://doi.org/10.1086/208508

Falk, P., \& Campbell, C. (Eds.). (1997). The shopping experience. Sage Publication. London, UK.

Forsythe, S.M., \& Bailey, A.W. (1996). Shopping enjoyment, perceived time poverty and time spent shopping. Journal of Clothing and Textiles Research, 14 (3), 185-191: https://doi.org/10.1177/0887302X9601400303

Freathy, P., \& O'Connell, F. (1999). Planning for profit: The commercialization of European airports. Long Range Planning, 32(6), 587-597.

Gerbing, W.D., Ahadi, A.S., \& Patton, H.J. (1987). Toward a conceptualization of impulsivity:

Components across the behavioral and self-report domains. Multivariate Behavioral Research, 22 (July), 357-379: https://doi.org/10.1207/s15327906mbr2203_6

Geuens, M., Vantomme, D., \& Brengman, M. (2004). Developing a typology of airport shoppers. Tourism Management, 25(5), 615-622.

Graham, A. (2009). How important are commercial revenues to today's airports? Journal of Air Transport Management, 15 (3), 106-111: https://doi.org/10.1016/j.jairtraman.2008.11.004

Hawes, J.M, \& Lumpkin, J.R. (1986). Perceived risk and the selection of a retail patronage mode. Journal of the Academy of Marketing Science, 14 (4), 37-42.

Higgins, T.E. (2006). Value from hedonic experience and engagement. American Psychological Association, 113 (3), 439-460: doi:10.1037/0033-295X.113.3.439

Hines, M.J., Hungerford, R.H., \& Tomera, N.A. (1987). Analysis and synthesis of research on responsible environmental behavior: A meta-analysis. The Journal of Environmental Education, 18 (2), 1-8: https://doi.org/10.1080/00958964.1987.9943482

Hirschman, E.C., \& Holbrook, M.B. (1982). Hedonic consumption: Emerging concepts, methods and propositions. The Journal of Marketing, 46 (Summer), 92-101.

Hofstede, G. (2001). Cultures consequences: comparing values, behaviors, institutions and organizations across nations, London: Sage Publications.

Hsieh, A.T., \& Chang, J. (2006). Shopping and tourist night markets in Taiwan. Tourism Management, 27 (1), $138-$ 145: https://doi.org/10.1016/j.tourman.2004.06.017

Ishii, K. (2009). Nationalistic sentiments of Chinese consumers: the effects and determinants of animosity and consumer ethnocentrism. Journal of International Consumer Marketing, 21 (4), 299-308:

https://doi.org/10.1080/08961530802282232

Jones, M., Reynolds, K., Weun, S., \& Beatty, S. (2003). The product-specific nature of impulse buying tendency. Journal of Business Research, 56 (7), 505-511: https://doi.org/10.1016/S0148-2963(01)00250-8 
Josiam, B.M., Kinley, T.R., \& Kim, Y.K. (2005). Involvement and the tourist shopper: Using the involvement construct to segment the American tourist shopper at the mall. Journal of Vacation Marketing, 11 (2), 135-154: https://doi.org/10.1177/1356766705052571

Kim, O.K, \& Jin, B. (2001). Korean consumers' patronage of discount stores: domestic vs. multinational discount store shoppers' profiles. The Journal of Consumer Marketing, 18 (3), 236-255: http://doi.org/10.1108/07363760110393092

Kim, M.S., \& Hunter, F.J. (1993). Attitude-behavior relations: A meta-analysis of attitudinal relevance and topic. Journal of Communication, 43 (1), 101-142: doi: 10.1111/j.1460-2466.1993.tb01251.x

Klein, G.J., Ettenson, R., \& Morris, D.M. (1998). The animosity model of foreign product purchase: an empirical test in the People's Republic of China. Journal of Marketing, 62 (1), 89-100: doi: 10.2307/1251805

Koufaris, M., Kambil, A., \& LaBarbera, P.A. (2001). Consumer behavior in web based commerce: an empirical study. International Journal of Electronic Commerce, 6 (2), 115-138:

https://doi.org/10.1080/10864415.2001.11044233

Laurent, G., \& Kapferer, J.N. (1985). Measuring consumer involvement profiles. Journal of Marketing Research, 22 (February), 41-53: doi: 10.2307/3151549

Levy, S.J. (1959). Symbols for sale, Harvard Business Review, 37, 117-119.

Lichtenstein, D.R., Bloch, P.H., \& Black, W.C. (1988). Correlates of price acceptability. Journal of Consumer Research, 15 (2), 243-252: https://doi.org/10.1086/209161

Majumder, A.I. (2014). Marketing tools in Understanding and Tackling a Growing Competition. Case: Sarban Duty Free Shop. MBA Program, School of Business, BRAC University. Internship Report.

Martineau, P. (1958). The personality of the retail store. Harvard Business Review, 36 (1), 47-55.

Marks, R.B. (1976). Operationalising the concept of store image. Journal of Retailing, 52 (3), 37-46.

McKenna, E. (2000). Business Psychology and Organizational Behavior, $3^{\text {rd }}$ ed., Psychology Press Limited, Hove.

Moeller, F.G., Barratt, S.E., Dougherty, M.D., Schmitz, M.J., \& Swann, C.A. (2001). Psychiatric: Aspects of impulsivity. The American Journal of Psychiatry, 158 (11), 1783-1793: http://doi.org/10.1176/appi.ajp.158.11.1783

Moodie, M. (2007). Analyzing airport commercial revenues. Airport Council International, ACI Airport Economics Survey, 20-25.

Newman, A.J., \& Foxall, G.R. (2003). In-store customer behavior in the fashion sector: some emerging methodological and theoretical directions. International Journal of Retail \& Distribution Management, 31 (11), 591600: https://doi.org/10.1108/09590550310503311

Odekerken-Schroeder, G., De Wulf, K., \& Schumacher, P. (2003). Strengthening outcomes of retailer-consumer relationships: the dual impact of relationship marketing tactics and consumer personality. Journal of Business Research, 56 (3), 177-190: https://doi.org/10.1016/S0148-2963(01) $\underline{00219-3}$

O'Guinn, T.C., \& Faber, R.J. (1989). Compulsive buying: a phenomenological exploration. Journal of Consumer Research, 16 (2), 147-157: https://doi.org/10.1016/S0148-2963(01)00219-3

Park, J.W., Choi, Y.J., \& Moon, W.C. (2013). Investigating the effects of sales promotions on customer behavioral intentions at duty free shops: an Incheon international airport case study. Journal of Airline and Airport Management, 3 (1), 18-30: https://doi.org/10.1016/S0148-2963(01) $\underline{00219-3}$

Rossiter, J.R., Percy, L., \& Donovan, J.R. (1991). A better advertising lanning grid. Journal of Advertising Research, 31 (5), 11-21: https://doi.org/10.1016/S0148-2963(수)00219-3

Rook, W.D. (1987). The buying impulse. Journal of Consumer Research, 14 (3), 189-199: https://doi.org/10.1086/209105

Rook, W.D., \& Fisher, R.J. (1995). Normative influences on impulsive buying behavior. Journal of Consumer Research, 22 (3), 305-313: https://doi.org/10.1086/209452

Rook, W.D, \& Gardner, P.M. (1993). In the Mood: Impulse buying's affective antecedents. Pages 1-28 in Janeen Arnold-Costa and Russell W. Belk (Eds.), Research in Consumer Behavior, 6 (6). Greenwich, CT: JAI Press.

Rook., W.D., \& Hoch, J.S. (1985). Consuming impulses. Pages 23-27, in Morris B. Holbrook and Elizabeth C. Hirschman (Eds.), Advances in Consumer Research, 12, Provo, UT: Association for Consumer Research. 
Rothschild, M.L. (1979). Advertising Strategies for High and Low Involvement Situations. In Attitude Research Plays for High Stakes, J. C. Maloney and B. Silverman, eds. Chicago: American Marketing Association, 74-93.

Shahjehan, A., Qureshi, A.J., Zeb, F., \& Saifullah, K. (2012). The effect of personality on impulsive and compulsive buying behaviors. African Journal of Business Management, 6 (6), 2187-2194.

Sheppard, B.H., Hartwick, J., \& Warshaw, P.R. (1988). The theory of reasoned action: Ameta-analysis of past research with recommendations for modifications and future research. Journal of Consumer Research, 15 (December), 325-343: https://doi.org/10.1086/209170

Shepherd, G.J., \& O’Keefe, D.J. (1984). Separability of attitudinal and normative influences on behavioral intentions in the Fishbein-Ajzen model, The Journal of Social Psychology, 122 (2), 287-288:

https://doi.org/10.1080/00224545.1984.9713496

Shim, S., \& Gehrt, K.C. (1996). Hispanic and Native American adolescents: an exploratory study of their approach to shopping. Journal of Retailing, 72 (3), 307-324: https://doi.org/10.1016/S0022-4359(96)

Sirgy, M.J., \& Coskun, S.A. (1985). A path analytic model of store loyalty involving self-concept, store image, geographic loyalty, and socioeconomic status. Journal of the Academy of Marketing Science, 13 (3), 265-291: https://doi.org/10.1177/009207038501300319

Snepenger, J.D, Murphy, L., O'Connell, R., \& Gregg, E. (2003). Tourists and residents use of a shopping space. Annals of Tourism Research, 30 (3), 567-580: https://doi.org/10.1016/S0160-7383(03)

Solomon, M.R. (2007). Consumer behavior: A European perspective enhanced media edition rack, $3^{\text {rd }}$ ed. Financial Times Management.

Sullivan, P., \& Heitmeyer, J. (2008). Looking at Gen Y shopping preferences and intentions: exploring the role of experience and apparel involvement. International Journal of Consumer Studies, 32 (3), 285-295: doi: 10.1111/j.1470-6431.2008.00680.x

Summers, T., \& Hebert, P. (2001). Shedding some light on store atmospheric: Influence of illumination on consumer behavior, Journal of Business Research, 54 (2), 145-150: https://doi.org/10.1016/S0148$\underline{2963}(\underline{99}) \underline{00082-X}$

Tarkiainen, A., \& Sundqvist, S. (2005). Subjective norms, attitudes and intentions of Finnish consumers in buying organic food. British food journal, 107 (11), 808-822: http://doi.org/10.1108/ 00070700510629760

Thomas, D. (1997). Retail and leisure developments at London Gatwick. Commercial Airport, 38, 41.

Unger, L.S., \& Kernanm, J.B. (1983). On the meaning of leisure: An investigation of some determinants of the subjective experience. Journal of Consumer Research, 9 (4), 381-392: https://doi.org/10.1086/208932

Verbeke, W., \& Vackier, I. (2004). Profile and effects of consumer involvement in fresh meat. Meat Science, 67 (1), 159-168: https://doi.org/10.1016/j.meatsci.2003.09.017

Verma, P. (2013). Framework for music as store atmospherics to induce buying: A study of Delhi mall customers. Portuguese Journal of Management Studies, 18 (2), 81-99.

Vermeir, I., \& Verbeke, W. (2006). Sustainable food consumption: Exploring the consumer "attitude-behavioral intention" gap. Journal of Agricultural and Environmental ethics, 19 (2), 169-194.

Vester, H. (1996). Die shopping mall: Eine touristisch destination der postmoderne. Gruppendynamic, 27, 57-62.

Vigneron, F., \& Johnson, L.W. (1999). A review and conceptual framework of prestige seeking consumer behavior. Academy of Marketing Science Review, 1999 (1), 1-15.

Wong, Y.T., Osman, S., Jamaluddin, A., \& Yin-Fah, B.C. (2012). Shopping motives, store attributes and shopping enjoyment among Malaysian youth. Journal of Retailing and Consumer Services, 19 (2), 240-248: https://doi.org/10.1016/j.jretconser.2012.01.005

Wu, B.T., \& Petroshius, S.M. (1987). The halo effect in store image measurement. Journal of the Academy of Marketing Science, 15 (3), 44-51.

Yüksel, A. (2007). Tourist shopping habitat: Effects on emotions, shopping value and behaviors. Tourism Management, 28 (1), 58-69: https://doi.org/10.1016/j.tourman.2005.07.017

Zaichkowsky, J.L. (1985). Measuring the involvement construct. Journal of Consumer Research, 12 (3), 341-352: https://doi.org/10.1086/208520

Zeithaml, A.V. (1988). Consumer perceptions of price, quality, and value: A means-end model and synthesis of evidence. Journal of Marketing, 52 (July), 2-22: doi: 10.2307/1251446 